Article

\title{
Synergistic Effects of Acacia Prunings-Derived Biochar and Nitrogen Application on the Mineral Profile of Maize (Zea mays L.) Grains
}

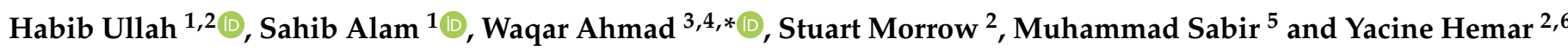 \\ 1 Department of Agricultural Chemistry and Biochemistry, The University of Agriculture, \\ Peshawar 25130, Pakistan; noorezi121@gmail.com (H.U.); dralam@aup.edu.pk (S.A.) \\ 2 School of Chemical Science, The University of Auckland, Auckland 1142, New Zealand; \\ stuart.morrow@auckland.ac.nz (S.M.); y.hemar@auckland.ac.nz (Y.H.) \\ 3 School of Agriculture and Food Sciences, The University of Queensland, St. Lucia, QLD 4072, Australia \\ 4 National Centre of Excellence in Geology, University of Peshawar, Peshawar 25000, Pakistan \\ 5 Institute of Soil and Environmental Sciences, University of Agriculture, Faisalabad 38000, Pakistan; \\ cmsuaf@gmail.com \\ 6 Institute for Advanced Study, Shenzhen University, Shenzhen 518060, China \\ * Correspondence: a.waqar@uq.edu.au; Tel.: +61-469-052-302
}

check for updates

Citation: Ullah, H.; Alam, S.;

Ahmad, W.; Morrow, S.; Sabir, M.; Hemar, Y. Synergistic Effects of Acacia Prunings-Derived Biochar and Nitrogen Application on the Mineral Profile of Maize (Zea mays L.) Grains. Sustainability 2022, 14, 2995.

https://doi.org/10.3390/su14052995

Academic Editor: Svein

Øivind Solberg

Received: 17 January 2022

Accepted: 1 March 2022

Published: 4 March 2022

Publisher's Note: MDPI stays neutral with regard to jurisdictional claims in published maps and institutional affiliations.

Copyright: (C) 2022 by the authors. Licensee MDPI, Basel, Switzerland. This article is an open access article distributed under the terms and conditions of the Creative Commons Attribution (CC BY) license (https:// creativecommons.org/licenses/by/ $4.0 /)$.

\begin{abstract}
Despite the proven impact of biochar (BC) on crop yield, little is known about its effect on cereal grain quality. We explored the effect of acacia pruning-derived biochar and nitrogen (N) applications on the mineral profile of maize grains in a field study. Biochar was applied at the rates of 5 , 10, 15, and $20 \mathrm{t} \mathrm{ha}^{-1}$ and $\mathrm{N}$ at 100, 150, and $200 \mathrm{~kg} \mathrm{ha}^{-1}$ along with the control (BC or $\mathrm{N}$ not applied) in a split-plot arrangement using a randomized complete block design. At crop maturity, the grains were analyzed for $\mathrm{K}, \mathrm{P}, \mathrm{Ca}, \mathrm{Mg}, \mathrm{Zn}, \mathrm{Fe}$, and $\mathrm{Cu}$ content. The results showed that $\mathrm{BC}$ application at the rate of $10 \mathrm{tha}^{-1}$ along with $\mathrm{N}$ at $200 \mathrm{~kg} \mathrm{ha}^{-1}$ resulted in the highest concentrations of $\mathrm{K}, \mathrm{P}, \mathrm{Ca}$, and $\mathrm{Mg}$ in grains. The Fe content was the maximum at the $\mathrm{N}$ application rate of $200 \mathrm{~kg} \mathrm{ha}^{-1}$ while $\mathrm{Zn}$ and $\mathrm{Cu}$ had the highest concentration at $150 \mathrm{~kg} \mathrm{~N} \mathrm{ha}^{-1}$ with no BC. It was concluded that the integrated use of BC and $\mathrm{N}$ could be a valuable strategy to improve the nutritional quality of maize grains. The enrichment of $\mathrm{BC}$ with micronutrients is recommended to achieve the desired concentration of micronutrients in maize grains to help cure malnutrition. However, further investigation is warranted to validate the impact of BC made of different feedstocks on soils of contrasting mineralogy as organo-mineral interactions might mask the true potential of BC.
\end{abstract}

Keywords: biochar; nitrogen fertilization; natural resource management; minerals; maize grain; circular economy

\section{Introduction}

Maize (Zea mays L.) is a staple cereal due to its high nutritional value. Maize is rich in phosphorus $(\mathrm{P})$, zinc $(\mathrm{Zn})$, iron $(\mathrm{Fe})$, and various vitamins. After wheat flour, maize flour is the most consumed flour and with lower calories compared to wheat flour [1]. High in proteins and starch with abundant antioxidants, maize flour helps in the prevention of anemia, and cancer [2]. To sustain a healthy life, our body needs many essential minerals, that are sometimes divided into macro-minerals and micro-minerals. Phosphorus $(\mathrm{P})$, potassium $(\mathrm{K})$, calcium $(\mathrm{Ca})$, and magnesium $(\mathrm{Mg})$ are amongst the macro-minerals. The main functions of $\mathrm{P}$ are the formation of bones and teeth, maintenance of acid-base balance, and protein formation, while $\mathrm{K}$ is needed for proper fluid balance, nerve transmission, and muscle contraction [3,4]. Our body needs Ca to circulate blood, move muscles, and release hormones. The regulation of muscle and nerve functions, blood sugar levels, blood pressure, and protein formation are controlled by $\mathrm{Mg}[5,6]$. Zinc, $\mathrm{Fe}$, and copper $(\mathrm{Cu})$ are the micro-minerals essential for adequate body functioning. For example, the functions 
of $\mathrm{Zn}$ include but are not limited to helping people resist infectious diseases and healthy pregnancies [7]. About 70\% of the body's Fe is found in hemoglobin (red blood cells) and myoglobin (muscle cells) which are responsible for the transport of oxygen from the lung to the cells. Likewise, $\mathrm{Cu}$ is an essential part of many enzymes and along with Fe it helps in the formation of red blood cells, prevents osteoporosis, and maintains healthy blood vessels, nerves, and immune functions [8].

In total, $18 \%$ of Pakistan's population are undernourished, $45 \%$ are facing severe stunting (low height-for-age), $15 \%$ are wasting (low weight-for-height), and 30\% are underweight because of multi-faceted malnutrition $[9,10]$. The deficiency of micro-minerals such as $\mathrm{Zn}$ and Fe is negatively affecting human health and is a country-wide serious public health nutrition concern. For instance, in Pakistan, $\mathrm{Zn}$ deficiency is an emerging health problem as approximately $20.6 \%$ of children have blood Zn levels below $60 \mu \mathrm{g} \mathrm{dL} \mathrm{d}^{-1}$. Studies have shown that anemia affects $41-77 \%$ of women of reproductive age in Pakistan [11]. The severity of anemia is more common in rural areas, where it is often associated with poor health outcomes such as postpartum hemorrhage, preterm or stillbirth, and low birth weight infants [12].

The severity of malnutrition due to micronutrients deficiency, in particular, has been linked with their low intake through staple food, and the strategies to further improve the quality and quantity of micro- and macronutrients have been the subjects of intense research. Farm-level strategies are being devised to target both quality and quantity parameters [13]. In this regard, the addition of organic wastes and manures has been successfully practiced ensuring adequate nutrient supply to the crops. However, the benefits of such added organic matter (OM) are often short-lived particularly in semiarid environments due to its rapid decomposition to $\mathrm{CO}_{2}$ within only a few cropping seasons. To sustain a steady supply of nutrients to the plants, OM should be available in the soil for a longer period. This could be successfully achieved with the addition of a stable OM source which should serve as a sink of carbon (C) on agricultural lands. Biochar (BC) is a pyrolyzed biomass and consists mostly of pyrogenic $C$, which takes longer to decompose than the biomass from which it is generated. The application of $\mathrm{BC}$ as a soil additive is vital due to its characteristics, which are responsible for enhancing agricultural productivity through nutrient retention, alleviating environmental problems, and combatting climate change [14,15]. The stable aromatic form of OC is an integral component of $\mathrm{BC}$, and its intended purpose of use distinguishes it from charcoal. BC application is attracting increasing interest as a sustainable technology in Pakistan to improve even highly degraded soils. Besides improving the crop yields, BC application has been shown to increase the crop nutrient uptake, globally. For example, the $\mathrm{N}$ uptake in cereals and vegetables was significantly improved in tropical soils under both greenhouse and field-scale experiments [16,17]. Previous studies have shown that BC application has a positive impact on the yield and nutritional quality of maize grain in greenhouse experiments [18]. Similarly, results from semi-arid soil in Australia showed a positive response to $\mathrm{BC}$ in combination with fertilizer in pot trials [19]. In Indonesia, maize and wheat yields were enhanced significantly where charcoal was integrated with $\mathrm{N}$ fertilizer in the field [20]. Thus, it is expected that the combined application of $\mathrm{BC}$ and $\mathrm{N}$ fertilizer will have a paramount influence on the nutrient concentrations in maize grains. Therefore, this study was undertaken to investigate the effectiveness of $\mathrm{BC}$ and its interaction with $\mathrm{N}$ fertilizer in enhancing the mineral composition of maize grains under field conditions. We hypothesized that the application of $\mathrm{BC}$ alone or in combination with $\mathrm{N}$ will improve the concentration of macronutrients $(\mathrm{K}, \mathrm{P}, \mathrm{Ca}, \mathrm{Mg})$ and micronutrients $(\mathrm{Zn}, \mathrm{Fe}, \mathrm{Cu})$ in maize grains and help to cure the malnutrition of people in Pakistan.

\section{Material and Methods}

\subsection{Study Site and Biochar Field Trial}

This experiment was carried out in the district of Buner $\left(34^{\circ} 30^{\prime} 41^{\prime \prime} \mathrm{N} 72^{\circ} 29^{\prime} 02^{\prime \prime} \mathrm{E}\right)$, Khyber Pakhtunkhwa (KPK), Pakistan. The climate of Buner is classified as dry sub-tropical 
with mixed alluvial deposits, loess, and re-deposited loess as the parent material of most of the soils developed. Maize is one of the main crops grown along with other cereals, vegetables, and fruits [10]. The average annual minimum and maximum temperatures at the experimental site are $-1.92{ }^{\circ} \mathrm{C}$ and $41.50{ }^{\circ} \mathrm{C}$, respectively, while the average total annual rainfall has been $818.20 \mathrm{~mm}$ (Pakistan Meteorological Department) for the past twelve years, i.e., 2010-2022. The experiment included two factors: BC treatment $(0,5$, 10,15 , and $\left.20 \mathrm{t} \mathrm{ha}^{-1}\right)$ and $\mathrm{N}$ application $\left(0,100,150\right.$, and $\left.200 \mathrm{~kg} \mathrm{ha}^{-1}\right)$. The treatments were replicated three times. The experiment was laid out in a randomized complete block design (RCBD) with a split-plot arrangement. The BC treatments were assigned to the main plot and $\mathrm{N}$ to the sub-plots. The $\mathrm{BC}$ was produced from the prunings of acacia (Acacia nilotica) through slow pyrolysis at a temperature of $450{ }^{\circ} \mathrm{C}$ in a stainless-steel kiln. During $\mathrm{BC}$ preparation, the maximum temperature reached was $680^{\circ} \mathrm{C}$ after 20 min of ignition with an average temperature of $\sim 450{ }^{\circ} \mathrm{C}$ throughout the process. The properties of soil and $\mathrm{BC}$ are presented in Table 1. BC was applied at the time of seed bed preparation and urea $(46 \% \mathrm{~N})$ was applied in two equal splits, i.e., half at sowing time and the remaining half applied 30 days after emergence. The BC was spread and mixed into top $10 \mathrm{~cm}$ soil with a tractor-driven power hoe. The field was thoroughly ploughed with the help of a cultivator followed by planking and fine seedbed preparation. A local variety of maize, Azam (semi dent type; color white; maturity days 95), released by the Cereal Crop Research Institute, Pirsabak (Khyber Pakhtunkhwa, Pakistan) was used in this experiment. The NPK recommended rate for this variety in the country is $120: 60: 60 \mathrm{~kg} \mathrm{ha}^{-1}$, respectively.

Table 1. Soil and biochar properties before starting the field experiment.

\begin{tabular}{|c|c|c|}
\hline & Property & Mean \\
\hline \multirow{6}{*}{ Soil } & $\mathrm{pH} 1: 5 \mathrm{H}_{2} \mathrm{O}$ & $8.20 \pm 0.28$ \\
\hline & EC $1: 5 \mathrm{H}_{2} \mathrm{O}\left(\mathrm{dSm}^{-1}\right)$ & $0.37 \pm 0.04$ \\
\hline & $\mathrm{OM}(\%)$ & $0.95 \pm 0.06$ \\
\hline & Organic C (\%) & $0.55 \pm 0.03$ \\
\hline & Available P (mg kg $\left.{ }^{-1}\right)$ & $3.45 \pm 0.06$ \\
\hline & Available K (mg kg $\left.{ }^{-1}\right)$ & $61.5 \pm 4.24$ \\
\hline \multirow{7}{*}{ Biochar } & $\mathrm{pH} 1: 10 \mathrm{H}_{2} \mathrm{O}$ & $6.46 \pm 0.03$ \\
\hline & EC $1: 10_{\mathrm{H}_{2} \mathrm{O}}\left(\mathrm{dS} \mathrm{m}^{-1}\right)$ & $1.06 \pm 0.02$ \\
\hline & $\mathrm{pH}_{\mathrm{NaCl}}$ & $6.50 \pm 0.02$ \\
\hline & $\mathrm{EC}_{\mathrm{NaCl}}\left(\mathrm{dSm}^{-1}\right)$ & $1.90 \pm 0.01$ \\
\hline & Alkalinity $\left(\mathrm{mg} \mathrm{L}^{-1}\right)$ & 8.00 \\
\hline & Total organic $C\left(\mathrm{~g} \mathrm{~kg}^{-1}\right)$ & $568 \pm 2.0$ \\
\hline & Total N $\left(\mathrm{g} \mathrm{kg}^{-1}\right)$ & $9.5 \pm 0.10$ \\
\hline
\end{tabular}

Values are presented as means \pm standard deviation; $\mathrm{EC}=$ electrical conductivity; OM = organic matter.

\section{Soil Properties (Start of the Experiment)}

The soil at the experimental site was sandy loam (60\% sand, 30\% silt, and 10\% clay), and slightly alkaline with $\mathrm{pH}$ ranging from 7.92 to 8.48 and electrical conductivity (EC) from 0.33 to $0.41 \mathrm{dS} \mathrm{m}^{-1}$. The soil was marginal in organic matter (OM) with an average $\mathrm{OM} 0.95 \%$, and low in $\mathrm{P}$ and $\mathrm{K}$ contents (3.45 and $61.5 \mathrm{mg} \mathrm{kg}^{-1}$, respectively; Table 1).

\subsection{Assessment of Soil and Biochar Properties}

\subsubsection{Soil}

Mixed soil samples were randomly collected from three different locations in each experimental unit prior to sowing, at the reproductive and maturation stages of maize. Sampling was carried out at a depth of $15 \mathrm{~cm}$ using a manual auger. All the samples were collected in clean plastic bags, air dried in the laboratory, and ground prior to physicochemical evaluation. 


\section{Soil $\mathrm{pH}$ and Electrical Conductivity}

The soil sample $(10 \mathrm{~g})$ together with $50 \mathrm{~mL}$ of distilled water was taken in a conical flask to make 1:5 soil-water suspension. The soil-water suspension was shaken on a mechanical shaker for $30 \mathrm{~min}$, then allowed to stand for $10 \mathrm{~min}$ before determining the $\mathrm{pH}$ using the $\mathrm{pH} 7$ and 10.0 standards. The electrical conductivity (EC) was also measured in the same suspension.

\section{Soil Organic Matter}

The determination of soil organic matter (SOM) was based on the Walkley-Black chromic acid wet oxidation method, and SOM was used as a proxy variable for soil $\mathrm{N}$. Oxidizable matter in the soil was oxidized by $1 \mathrm{~N} \mathrm{~K}_{2} \mathrm{Cr}_{2} \mathrm{O}_{7}$ solution. The reaction was assisted by the heat generated when two volumes of $\mathrm{H}_{2} \mathrm{SO}_{4}$ were mixed with one volume of the dichromate [21].

Plant-Available Phosphorus

The plant-available $\mathrm{P}$ was measured after digestion of $5 \mathrm{~g}$ of soil in $50 \mathrm{~mL}$ of $0.5 \mathrm{M}$ sodium bicarbonate solution, $\mathrm{pH} \sim 8.5$ [22]. For the spectrophotometric analysis, the color was developed through an ascorbic acid containing mixed indicator (ammonium molybdate and potassium antimony tartrate in $5 \mathrm{~N}$ sulfuric acid). An analysis of $\mathrm{P}$ was completed using the colorimetric technique on a spectrophotometer ((UV-6000, Newbury, UK).

\section{Plant-Available Potassium}

The plant-available $\mathrm{K}$ was measured after extracting $2.5 \mathrm{~g}$ of soil using $25 \mathrm{~mL}, 1.0 \mathrm{~N}$, $\mathrm{pH} \sim 7$, and ammonium acetate [23]. Necessary dilutions were completed to determine $\mathrm{K}$ using a flame photometer (Model Sherwood 420, Sherwood, UK).

\section{Soil Texture}

Sand, silt, and clay fractions were determined by the soil suspension density $(1: 20 \mathrm{~m} / \mathrm{v})$ in a $1 \mathrm{~L}$ volumetric flask. The silt and clay densities were recorded after $40 \mathrm{~s}$, while the clay density was recorded after $2 \mathrm{~h}$ using a hydrometer. Sodium hexa-metaphosphate was used to disperse the soil particles. A blank reading was also taken and corrected for temperature variations.

\subsubsection{Biochar}

$\mathrm{pH}$ and Electrical Conductivity

The EC and $\mathrm{pH}$ were measured in 1:10 solid/water suspensions using a digital EC and $\mathrm{pH}$ meter. The $\mathrm{pH}$ of $\mathrm{BC}$ was measured twice by mixing it with deionized (DI) water in a $\mathrm{BC}$ : water $(w / v)$ ratio of $1: 10$. The resulting suspensions were equilibrated for $1 \mathrm{~h}$, then the $\mathrm{pH}$ was measured by placing an electrode in the solution just above the settled BC.

Total Carbon and Nitrogen

The $B C$ sub-sample was ground to obtain a $<53 \mu \mathrm{m}$ fraction. The total $C$ and $N$ contents of BC were determined by dry combustion using a Vario Max CNS analyzer (Elementar Analysensysteme GmbH, Hanau, Germany).

\section{Alkalinity}

The $\mathrm{pH}$ of $\mathrm{BC}$ was measured by equilibrating $0.3 \mathrm{~g}$ of $\mathrm{BC}$ with $15 \mathrm{~mL}$ of $1 \mathrm{M} \mathrm{NaCl}$ for $24 \mathrm{~h}$. The samples were filtered, and the $\mathrm{pH}$ of the $\mathrm{NaCl}$ extract was measured. The total alkalinity of $\mathrm{BC}$ was quantified by the reaction with $\mathrm{HCl}$ and subsequent back titration. First, $\mathrm{BC}$ was rapidly shaken (on an automatic shaker) with the $\mathrm{HCl}$ solution at a BC:solution $(w / v)$ ratio of 1:50. The shaking intervals were $2,4,6,8,10,12,24,48$, and $72 \mathrm{~h}$. The $\mathrm{BC}$-solution suspensions were then filtered, and the extracts were titrated to $\mathrm{pH} 8.2$ with standardized $0.05 \mathrm{M} \mathrm{NaOH}$ in the presence of the phenolphthalein indicator. The total 
alkalinity (mmol of $\mathrm{H}^{+}$reacted $\mathrm{g}^{-1}$ of air-dried BC) was calculated from the difference between the amount of acid titrated in the sample and the blank.

\section{Post-Harvest Analyses of Maize Grains}

Maize plants were harvested at maturity (after 95 days). Grains were removed from the cobs by a method wherein the cob was first split longitudinally. Then, a force was applied to remove them from the cob. Composite samples of grain, each of $1 \mathrm{~kg}$, were collected from each treatment. The composite samples were reduced to laboratory size samples (100 g each), dried to a constant weight at $65^{\circ} \mathrm{C}$ in a forced-air oven, and then sub-samples were finely ground using a Retsch MM400 mixer mill (RETSCH GmbH, Haan, Germany). The finely ground samples were analyzed for mineral composition, i.e., macronutrients $(\mathrm{K}$, $\mathrm{P}, \mathrm{Ca}, \mathrm{Mg})$, and micronutrients $(\mathrm{Zn}, \mathrm{Fe}, \mathrm{Cu})$. The samples were analyzed by the method of Rui et al. [24], using an inductively coupled plasma mass spectrometry (ICP-MS) (Agilent 7700 ICP-MS, Agilent, Santa Clara, CA, USA). Briefly, $200 \mathrm{mg}$ of the finely ground maize grain sample along with $5 \mathrm{~mL}$ of $69 \% \mathrm{HNO}_{3}$ (Tracepur, Merck) and $100 \mu \mathrm{L}$ of the internal standard solution $\left(10 \mu \mathrm{g} \mathrm{mL}^{-1}\right.$ scandium in $\left.5 \% \mathrm{HNO}_{3}\right)$ were added in the reaction vessel for microwave digestion (Ethos-Up with Maxi-44 Rotor, Milestone SLR, Sorisole, Italy). The vessels were heated to $200{ }^{\circ} \mathrm{C}$ over $15 \mathrm{~min}$, held at the same temperature (for $20 \mathrm{~min}$ ), and cooled to an ambient temperature (over $30 \mathrm{~min}$ ). Samples were then removed from the microwave and the volumes were made up to $50 \mathrm{~mL}$ with ultra-pure water (resistivity of $>18 \mathrm{M} \Omega-\mathrm{cm}$, conductivity of $<0.056 \mu \mathrm{S} \mathrm{cm}{ }^{-1}$, and $<50$ parts per billons of total organic carbon). Calibration standards were prepared in a matrix matched solution from $1000 \mathrm{ppm}$ single element standards (Peak Performance, CPI International, Palo Alto, CA, USA). An internal standard (5 ppb Terbium) was used to monitor and correct for instrument drift and matrix effects. The standards were run on the ICP-MS and an external calibration curve was generated. A $15 \mathrm{~mL}$ aliquot of each sample was taken in a centrifuge tube and injected into the ICP-MS for the elemental analysis in triplicate.

\section{Statistical Analysis}

The data were subjected to an analysis of variance (ANOVA) using the Statistix 8.1 statistical package. The significant differences between treatment means were determined using the least significant difference (LSD) test for main as well as for interactive effects. The effects of $\mathrm{BC}\left(0,5,10,15\right.$, and $\left.20 \mathrm{tha}^{-1}\right), \mathrm{N}$ fertilizer $\left(0,100,150\right.$, and $\left.200 \mathrm{~kg} \mathrm{ha}^{-1}\right)$, and the $\mathrm{BC} \times \mathrm{N}$ were estimated with a two-way ANOVA on all the measured data. To reflect the impact of BC (averaged across $\mathrm{N}$ levels) visually and statistically, and N (averaged across $\mathrm{BC}$ levels) on the grain density of macro- and micronutrients, different regression techniques were employed, and the one with the highest values of the co-efficient of determination $\left(R^{2}\right)$ was chosen.

\section{Results}

\subsection{Changes in Soil pH, EC, and OM (at Reproductive Stage and after Harvest)}

Variations in soil parameters were found at the reproductive stage of maize while no changes in these parameters were observed after maize harvest (ripening stage) (Tables 2 and 3). It was observed that the individual effects of $\mathrm{BC}$ and $\mathrm{N}$ were significant $(p \leq 0.05)$ on soil $\mathrm{pH}$; however, the $\mathrm{BC} \times \mathrm{N}$ interactive effect was non-significant $(p>0.05)$. Similarly, BC and its interaction with $\mathrm{N}$ also showed a significant $(p \leq 0.05)$ effect on SOM. In contrast, the effect of $\mathrm{N}$ was not significant $(p>0.05)$. BC and $\mathrm{N}$ showed no significant $(p>0.05)$ effects on the soil EC. The average soil $\mathrm{pH}$ values indicated that the soil $\mathrm{pH}$ was maximum (7.81) with $20 \mathrm{t} \mathrm{ha}^{-1}$ which was statistically similar to $15 \mathrm{t} \mathrm{ha}^{-1} \mathrm{BC}$. The $\mathrm{pH}$ of the soil was the lowest (7.76) with $10 \mathrm{tha}^{-1} \mathrm{BC}$. The soil $\mathrm{pH}$ peaked at $\sim 7.86$ with the $100 \mathrm{~kg} \mathrm{ha}^{-1} \mathrm{~N}$ application followed by $150 \mathrm{~kg} \mathrm{ha}^{-1}$. The lowest soil $\mathrm{pH} \sim 7.78$ was observed with the $\mathrm{N}$ application at $200 \mathrm{~kg} \mathrm{ha}^{-1}$. The maximum SOM $(0.79 \sim 39 \%$ increase $)$ was noticed with the $\mathrm{BC}$ application rate of $10 \mathrm{tha}^{-1}$ followed by $5 \mathrm{tha}^{-1}$, and the lowest $(0.57 \%)$ was without BC. The EC values non-significantly varied from 0.27 to $0.30 \mathrm{dS} \mathrm{m}^{-1}$ 
among various treatments. At the maturity stage of the crop, the mean $\mathrm{pH}$ and SOM values tended to decrease slightly while the soil EC remained unchanged (Table 3).

Table 2. Soil properties at the reproductive stage of maize as affected by different biochar (BC) and nitrogen $(\mathrm{N})$ levels.

\begin{tabular}{|c|c|c|c|c|c|c|}
\hline & \multirow{2}{*}{ Biochar (t ha $\left.{ }^{-1}\right)$} & \multicolumn{4}{|c|}{ Nitrogen $\left(\mathrm{kg} \mathrm{ha}^{-1}\right)$} & \multirow{2}{*}{ Means } \\
\hline & & 0 & 100 & 150 & 200 & \\
\hline \multirow{6}{*}{$\mathrm{pH}$} & 0 & $7.74 \pm 0.03$ ef & $7.90 \pm 0.03 \mathrm{ab}$ & $7.90 \pm 0.05 \mathrm{ab}$ & $7.77 \pm 0.13 \mathrm{c}-\mathrm{f}$ & $7.83 \pm 0.09 \mathrm{AB}$ \\
\hline & 5 & $7.83 \pm 0.06 \mathrm{~b}-\mathrm{f}$ & $7.78 \pm 0.03 \mathrm{c}-\mathrm{f}$ & $7.76 \pm 0.04$ def & $7.80 \pm 0.02 b c-f$ & $7.79 \pm 0.03 \mathrm{BC}$ \\
\hline & 10 & $7.72 \pm 0.05 \mathrm{f}$ & $7.82 \pm 0.07 \mathrm{~b}-\mathrm{f}$ & $7.77 \pm 0.01 \mathrm{c}-\mathrm{f}$ & $7.75 \pm 0.03$ ef & $7.76 \pm 0.04 \mathrm{C}$ \\
\hline & 15 & $7.88 \pm 0.12 \mathrm{a}-\mathrm{d}$ & $7.84 \pm 0.03 \mathrm{a}-\mathrm{e}$ & $7.91 \pm 0.04 \mathrm{ab}$ & $7.82 \pm 0.13 b c-f$ & $7.86 \pm 0.04 \mathrm{~A}$ \\
\hline & 20 & $7.87 \pm 0.03 \mathrm{a}-\mathrm{d}$ & $7.95 \pm 0.17 \mathrm{a}$ & $7.88 \pm 0.03 \mathrm{a}-\mathrm{c}$ & $7.75 \pm 0.03$ ef & $7.86 \pm 0.09 \mathrm{~A}$ \\
\hline & Mean & $7.81 \pm 0.08 \mathrm{AB}$ & $7.86 \pm 0.07 \mathrm{~A}$ & $7.84 \pm 0.07 \mathrm{~A}$ & $7.78 \pm 0.03 \mathrm{~B}$ & \\
\hline \multirow{6}{*}{$\mathrm{SOM}$} & 0 & $0.46 \pm 0.02 \mathrm{fg}$ & $0.54 \pm 0.05 \mathrm{abc}$ & $0.71 \pm 0.05 \mathrm{abc}$ & $0.55 \pm 0.04 \mathrm{efg}$ & $0.57 \pm 0.10 \mathrm{C}$ \\
\hline & 5 & $0.68 \pm 0.02 \mathrm{~cd}$ & $0.67 \pm 0.12 b c$ & $0.70 \pm 0.07 \mathrm{bc}$ & $0.73 \pm 0.10 \mathrm{abc}$ & $0.69 \pm 0.03 \mathrm{~B}$ \\
\hline & 10 & $0.79 \pm 0.04 \mathrm{abc}$ & $0.83 \pm 0.12 \mathrm{abc}$ & $0.78 \pm 0.03 \mathrm{abc}$ & $0.75 \pm 0.03 a b c$ & $0.79 \pm 0.03 \mathrm{~A}$ \\
\hline & 15 & $0.81 \pm 0.06 \mathrm{ab}$ & $0.43 \pm 0.04 \mathrm{fg}$ & $0.47 \pm 0.03 \mathrm{fg}$ & $0.56 \pm 0.03 \mathrm{def}$ & $0.57 \pm 0.17 \mathrm{C}$ \\
\hline & 20 & $0.53 \pm 0.04 \mathrm{fg}$ & $0.75 \pm 0.14 \mathrm{fg}$ & $0.43 \pm 0.03 \mathrm{fg}$ & $0.67 \pm 0.18$ cde & $0.60 \pm 0.14 \mathrm{C}$ \\
\hline & Mean & $0.65 \pm 0.15 \mathrm{~A}$ & $0.64 \pm 0.16 \mathrm{~A}$ & $0.62 \pm 0.15 \mathrm{~A}$ & $0.65 \pm 0.09 \mathrm{~A}$ & \\
\hline \multirow{6}{*}{$\mathrm{EC}$} & 0 & $0.26 \pm 0.02 \mathrm{ab}$ & $0.31 \pm 0.04 \mathrm{ab}$ & $0.32 \pm 0.04 \mathrm{a}$ & $0.25 \pm 003 \mathrm{ab}$ & $0.29 \pm 0.04 \mathrm{~A}$ \\
\hline & 5 & $0.29 \pm 0.03 \mathrm{ab}$ & $0.23 \pm 0.01 \mathrm{~b}$ & $0.27 \pm 0.04 \mathrm{ab}$ & $0.29 \pm 0.05 \mathrm{ab}$ & $0.27 \pm 0.03 \mathrm{~A}$ \\
\hline & 10 & $0.31 \pm 0.07 \mathrm{ab}$ & $0.27 \pm 0.03 \mathrm{ab}$ & $0.27 \pm 0.03 \mathrm{ab}$ & $0.28 \pm 0.05 \mathrm{ab}$ & $0.28 \pm 0.02 \mathrm{~A}$ \\
\hline & 15 & $0.30 \pm 0.07 \mathrm{ab}$ & $0.30 \pm 0.07 \mathrm{ab}$ & $0.32 \pm 0.08 \mathrm{a}$ & $0.29 \pm 0.08 \mathrm{ab}$ & $0.30 \pm 0.01 \mathrm{~A}$ \\
\hline & 20 & $0.30 \pm 0.07 \mathrm{ab}$ & $0.28 \pm 0.03 \mathrm{ab}$ & $0.32 \pm 0.05 \mathrm{a}$ & $0.27 \pm 0.02 \mathrm{ab}$ & $0.29 \pm 0.02 \mathrm{~A}$ \\
\hline & Mean & $0.29 \pm 0.02 \mathrm{~A}$ & $0.28 \pm 0.03 \mathrm{~A}$ & $0.30 \pm 0.03 \mathrm{~A}$ & $0.28 \pm 0.02 \mathrm{~A}$ & \\
\hline
\end{tabular}

Means in each category followed by different letters are significantly different at $p \leq 0.05$.

Table 3. Soil properties at the maturity stage of maize as affected by different biochar (BC) and nitrogen $(\mathrm{N})$ levels.

\begin{tabular}{|c|c|c|c|c|c|c|}
\hline & \multirow{2}{*}{$\operatorname{Biochar}\left(t \mathrm{ha}^{-1}\right)$} & \multicolumn{4}{|c|}{ Nitrogen $\left(\mathrm{kg} \mathrm{ha}^{-1}\right)$} & \multirow{2}{*}{ Means } \\
\hline & & 0 & 100 & 150 & 200 & \\
\hline \multirow{6}{*}{$\mathrm{pH}$} & 0 & $7.73 \pm 0.05 a b c$ & $7.85 \pm 0.07 \mathrm{ab}$ & $7.87 \pm 0.05 a$ & $7.73 \pm 0.13 \mathrm{abc}$ & $7.80 \pm 0.08 \mathrm{AB}$ \\
\hline & 5 & $7.75 \pm 0.05 \mathrm{abc}$ & $7.76 \pm 0.03 \mathrm{abc}$ & $7.73 \pm 0.06 \mathrm{abc}$ & $7.76 \pm 0.01 \mathrm{abc}$ & $7.75 \pm 0.02 \mathrm{BC}$ \\
\hline & 10 & $7.68 \pm 0.05 c$ & $7.80 \pm 0.06 \mathrm{abc}$ & $7.72 \pm 0.02 \mathrm{abc}$ & $7.72 \pm 0.03 \mathrm{bc}$ & $7.73 \pm 0.05 C$ \\
\hline & 15 & $7.77 \pm 0.26 \mathrm{abc}$ & $7.83 \pm 0.05 \mathrm{ab}$ & $7.83 \pm 0.11 \mathrm{ab}$ & $7.80 \pm 0.12 \mathrm{abc}$ & $7.81 \pm 0.03 \mathrm{~A}$ \\
\hline & 20 & $7.84 \pm 0.01 \mathrm{ab}$ & $7.85 \pm 0.11 \mathrm{ab}$ & $7.85 \pm 0.02 \mathrm{ab}$ & $7.72 \pm 0.04 b c$ & $7.81 \pm 0.06 \mathrm{~A}$ \\
\hline & Mean & $7.75 \pm 0.06 \mathrm{AB}$ & $7.82 \pm 0.04 \mathrm{~A}$ & $7.80 \pm 0.07 \mathrm{~A}$ & $7.75 \pm 0.03 \mathrm{~B}$ & \\
\hline \multirow{6}{*}{$\mathrm{SOM}$} & 0 & $0.54 \pm 0.05 \mathrm{fgh}$ & $0.50 \pm 0.01 \mathrm{~h}$ & $0.61 \pm 0.04$ cde & $0.53 \pm 0.03 \mathrm{gf}$ & $0.55 \pm 0.04 \mathrm{D}$ \\
\hline & 5 & $0.65 \pm 0.01 \mathrm{bc}$ & $0.65 \pm 0.01 \mathrm{bc}$ & $0.60 \pm 0.02 \mathrm{de}$ & $0.66 \pm 0.02 \mathrm{~b}$ & $0.64 \pm 0.03 \mathrm{~B}$ \\
\hline & 10 & $0.72 \pm 0.01 \mathrm{a}$ & $0.74 \pm 0.01 \mathrm{a}$ & $0.73 \pm 0.02 \mathrm{a}$ & $0.73 \pm 0.01 \mathrm{a}$ & $0.73 \pm 0.01 \mathrm{~A}$ \\
\hline & 15 & $0.71 \pm 0.01 \mathrm{a}$ & $0.36 \pm 0.07 \mathrm{bc}$ & $0.62 \pm 0.03$ bcde & $0.58 \pm 0.02 \mathrm{efg}$ & $0.57 \pm 0.15 \mathrm{D}$ \\
\hline & 20 & $0.59 \pm 0.2 \mathrm{de}$ & $0.58 \pm 0.02$ ef & $0.63 \pm 0.03 \mathrm{bcd}$ & $0.66 \pm 0.01 \mathrm{~b}$ & $0.61 \pm 0.04 \mathrm{C}$ \\
\hline & Mean & $0.64 \pm 0.08 \mathrm{~A}$ & $0.57 \pm 0.14 \mathrm{~B}$ & $0.64 \pm 0.05 \mathrm{~A}$ & $0.63 \pm 0.08 \mathrm{~A}$ & \\
\hline \multirow{6}{*}{$\mathrm{EC}$} & 0 & $0.26 \pm 0.02 \mathrm{ab}$ & $0.31 \pm 0.04 \mathrm{ab}$ & $0.32 \pm 0.04 \mathrm{a}$ & $0.25 \pm 0.03 \mathrm{ab}$ & $0.29 \pm 0.04 \mathrm{~A}$ \\
\hline & 5 & $0.29 \pm 0.03 \mathrm{ab}$ & $0.23 \pm 0.01 \mathrm{~b}$ & $0.27 \pm 0.04 \mathrm{ab}$ & $0.29 \pm 0.05 \mathrm{ab}$ & $0.27 \pm 0.03 \mathrm{~A}$ \\
\hline & 10 & $0.31 \pm 0.07 \mathrm{ab}$ & $0.27 \pm 0.03 \mathrm{ab}$ & $0.27 \pm 0.03 \mathrm{ab}$ & $0.28 \pm 0.05 \mathrm{ab}$ & $0.28 \pm 0.02 \mathrm{~A}$ \\
\hline & 15 & $0.30 \pm 0.07 \mathrm{ab}$ & $0.30 \pm 0.07 \mathrm{ab}$ & $0.32 \pm 0.08 \mathrm{a}$ & $0.29 \pm 0.08 \mathrm{ab}$ & $0.30 \pm 0.01 \mathrm{~A}$ \\
\hline & 20 & $0.30 \pm 0.07 \mathrm{ab}$ & $0.28 \pm 0.03 \mathrm{ab}$ & $0.32 \pm 0.05 \mathrm{a}$ & $0.27 \pm 0.02 \mathrm{ab}$ & $0.29 \pm 0.02 \mathrm{~A}$ \\
\hline & Mean & $0.29 \pm 0.02 \mathrm{~A}$ & $0.28 \pm 0.03 \mathrm{~A}$ & $0.30 \pm 0.03 \mathrm{~A}$ & $0.28 \pm 0.02 \mathrm{~A}$ & \\
\hline
\end{tabular}




\subsection{Grain Yield}

Data showed that the maize grain yield remained unaffected with the $\mathrm{BC}$ application alone and in combination with $\mathrm{N}(p>0.05$; Table 4$)$. However, the individual effect of $\mathrm{N}$ was significant $(p \leq 0.05)$ on maize yield. Maximum grain yield was recorded $\left(4762 \mathrm{~kg} \mathrm{ha}^{-1}\right)$ with the $\mathrm{N}$ application at $200 \mathrm{~kg} \mathrm{ha}^{-1}$, followed by $150 \mathrm{~kg} \mathrm{ha}^{-1}$. Minimum grain yield was observed for the control treatment (without BC and N, 27\% decreased yield as compared to the $\mathrm{N}$ application at $200 \mathrm{~kg} \mathrm{ha}^{-1}$ ). Overall, the grain yield was negatively correlated with the nutrient grain density $(\mathrm{r}=-0.540, p \leq 0.01)$.

Table 4. Effect of biochar (BC) and nitrogen (N) application on maize grain yield $\left(\mathrm{kg} \mathrm{ha}^{-1}\right)$.

\begin{tabular}{|c|c|c|c|c|c|}
\hline \multirow{2}{*}{ Biochar (t ha $\left.{ }^{-1}\right)$} & \multicolumn{4}{|c|}{ Nitrogen $\left(\mathrm{kg} \mathrm{ha}^{-1}\right)$} & \multirow{2}{*}{ Means } \\
\hline & 0 & 100 & 150 & 200 & \\
\hline 0 & $2602.7 \pm 41.04 \mathrm{k}$ & $3106.7 \pm 75.11 \mathrm{~h}$ & $4147.7 \pm 84.52 \mathrm{f}$ & $4678.0 \pm 46.2 \mathrm{e}$ & $3633.75 \pm 935.9 \mathrm{E}$ \\
\hline 5 & $2709.0 \pm 17.32 \mathrm{j}$ & $3145.3 \pm 38.9 \mathrm{gh}$ & $4277.7 \pm 15.37$ ef & $4587.7 \pm 27.32 \mathrm{~cd}$ & $3679.92 \pm 896.2 \mathrm{D}$ \\
\hline 10 & $2926.7 \pm 60.28 \mathrm{i}$ & $3425.3 \pm 24.73 \mathrm{~g}$ & $4507.3 \pm 17.04 \mathrm{~cd}$ & $4788.3 \pm 44.1 \mathrm{~cd}$ & $3911.92 \pm 881.3 \mathrm{C}$ \\
\hline 15 & $4058.0 \pm 86.88 \mathrm{f}$ & $4025.0 \pm 34.87 \mathrm{ef}$ & $4741.7 \pm 15.28 \mathrm{~cd}$ & $4616.0 \pm 71.51 \mathrm{bc}$ & $4360.17 \pm 371.8 \mathrm{~B}$ \\
\hline 20 & $4147.3 \pm 105.11 \mathrm{f}$ & $4030.7 \pm 30.01 \mathrm{~d}$ & $4645.0 \pm 45.64 b$ & $5141.3 \pm 96.06 \mathrm{a}$ & $4491.08 \pm 508.8 \mathrm{~A}$ \\
\hline Mean & $3288.7 \pm 752.8 \mathrm{D}$ & $3546.6 \pm 456.19 \mathrm{C}$ & $4463.9 \pm 248.26 \mathrm{~B}$ & $4762.3 \pm 225.5 \mathrm{~A}$ & \\
\hline
\end{tabular}

Means in each category followed by different letters are significantly different at $p<0.05$.

\subsection{Effect of Biochar and Nitrogen Application on Macronutrients in Maize Grain}

We found that $\mathrm{BC}$ and $\mathrm{N}$ levels significantly $(p \leq 0.05)$ affected the $\mathrm{K}$ content of maize grain (Table 5). Among the different levels of BC, the application rate of $10 \mathrm{tha}^{-1}$ resulted in a maximum grain $\mathrm{K}$ content $\sim 4834.68 \pm 492 \mathrm{mg} \mathrm{kg}^{-1}$ (12\% more than control) $>15 \mathrm{t} \mathrm{ha}^{-1} \sim 4671.47 \pm 250 \mathrm{mg} \mathrm{kg}^{-1}$ ( $8 \%$ more than the control). The lowest $\mathrm{K}$ content $\left(4319.23 \pm 139 \mathrm{mg} \mathrm{kg}^{-1}\right)$ was recorded in maize grain from the control plots (without BC). Regarding the $\mathrm{N}$ application, the grain $\mathrm{K}$ content increased consistently with increasing $\mathrm{N}$ levels. The lowest concentration of $\mathrm{K}\left(4278.72 \pm 160 \mathrm{mg} \mathrm{kg}^{-1}\right)$ was obtained in control samples, whereas the maximum concentration $\sim 4967.36 \pm 394 \mathrm{mg} \mathrm{kg}^{-1}$ was found in the samples from the treatment plots that received $200 \mathrm{~kg} \mathrm{ha}^{-1} \mathrm{~N}$. The combined effect of $\mathrm{BC}$ and $\mathrm{N}$ revealed that the grain $\mathrm{K}$ content was maximum at $10 \mathrm{tha}{ }^{-1} \mathrm{BC}$ along with $200 \mathrm{~kg} \mathrm{~N} \mathrm{ha}^{-1}$, and lowest in the control (without BC and N) (Table 5, Figure 1).

An analysis of variance showed that both $\mathrm{BC}$ and $\mathrm{N}$ levels, individually as well as interactively, significantly ( $p \leq 0.05$; Table 5 ) affected the P content of maize grain. The mean data values showed that BC applied at $10 \mathrm{tha}^{-1}$ yielded a maximum $\mathrm{P}$ content of $3705.52 \pm 325 \mathrm{mg} \mathrm{kg}^{-1}$ in maize grain, while the control treatment showed the least concentration of $\mathrm{P}$ viz. $3250.73 \pm 177 \mathrm{mg} \mathrm{kg}^{-1}$ in the grain. Among different $\mathrm{N}$ levels, the highest dose rate of $200 \mathrm{~kg} \mathrm{ha}^{-1}$ exhibited maximum P content $\left(3684.42 \pm 362 \mathrm{mg} \mathrm{kg}^{-1}\right)$ in the maize grain, followed by $150 \mathrm{~kg} \mathrm{ha}^{-1}$. Minimum $\mathrm{P}$ content $\left(3218.98 \pm 184 \mathrm{mg} \mathrm{kg}^{-1}\right)$ was recorded in grain without the $\mathrm{N}$ application. The interaction between $\mathrm{BC}$ and $\mathrm{N}$ levels revealed that the maximum grain $\mathrm{P}$ content $\left(4133.48 \pm 26 \mathrm{mg} \mathrm{kg}^{-1}\right)$ was found with the application of $10 \mathrm{tha}^{-1}$ of $\mathrm{BC}$ along with $200 \mathrm{~kg} \mathrm{~N} \mathrm{ha}^{-1}$, whereas the grain $\mathrm{P}$ content was the lowest (3002.72 $\pm 20 \mathrm{mg} \mathrm{kg}^{-1}$ ) with the $\mathrm{BC}$ application at $20 \mathrm{t} \mathrm{ha}^{-1}$ alone.

The effect of both $\mathrm{BC}$ and $\mathrm{N}$ as well as $\mathrm{BC} \times \mathrm{N}$ on the $\mathrm{Ca}$ content of grains was significant $\left(p \leq 0.05\right.$; Table 5). The maximum average content of $\mathrm{Ca}\left(231.07 \pm 17 \mathrm{mg} \mathrm{kg}^{-1}\right)$ was analyzed in grain samples at $10 \mathrm{t} \mathrm{ha}^{-1} \mathrm{BC}$, whereas the lowest amount of $\mathrm{Ca}\left(189.88 \pm 11.86 \mathrm{mg} \mathrm{kg}^{-1}\right)$ was examined in the samples collected from the control (without $\mathrm{BC}$ and $\mathrm{N}$ ). The interactive effect of $\mathrm{BC}$ and $\mathrm{N}$ indicated that $\mathrm{BC}$ treatment at $20 \mathrm{tha}^{-1}$ without $\mathrm{N}$ resulted in the lowest Ca content $(155.15 \pm 6.50 \mathrm{mg} \mathrm{kg})$, whereas the $\mathrm{BC}$ at $10 \mathrm{tha}^{-1}$ and $\mathrm{N}$ level of $200 \mathrm{~kg} \mathrm{ha}^{-1}$ caused the maximum Ca content $\left(247.60 \pm 5.06 \mathrm{mg} \mathrm{kg}^{-1}\right)$ in maize grain. 
Table 5. Macro-elements' concentration of maize grains $\left(\mathrm{mg} \mathrm{kg}^{-1}\right)$ as affected by different biochar $(\mathrm{BC})$ and nitrogen $(\mathrm{N})$ levels.

\begin{tabular}{|c|c|c|c|c|c|c|}
\hline \multirow{2}{*}{ Element } & \multirow{2}{*}{ Biochar (t ha-1) } & \multicolumn{4}{|c|}{ Nitrogen $\left(\mathbf{k g ~ h a}^{-1}\right)$} & \multirow{2}{*}{ Mean } \\
\hline & & 0 & 100 & 150 & 200 & \\
\hline \multirow{6}{*}{$\mathrm{K}$} & 0 & $4133.09 \pm 26.14 \mathrm{~h}$ & $4330.52 \pm 4.43 \mathrm{fgh}$ & $4342.71 \pm 23.37 \mathrm{fgh}$ & $4470.60 \pm 7.74 \mathrm{efg}$ & $4319.23 \pm 139.33 \mathrm{D}$ \\
\hline & 5 & $4225.53 \pm 9.511 \mathrm{gh}$ & $4325.20 \pm 18.69 \mathrm{fgh}$ & $4369.28 \pm 11.65 \mathrm{fgh}$ & $5054.11 \pm 6.88 \mathrm{~b}$ & $4493.53 \pm 378.28 \mathrm{C}$ \\
\hline & 10 & $4520.30 \pm 13.44$ ef & $4496.77 \pm 9.05 \mathrm{ef}$ & $4772.54 \pm 3.79 \mathrm{~cd}$ & $5549.09 \pm 27.45 \mathrm{a}$ & $4834.68 \pm 492.36 \mathrm{~A}$ \\
\hline & 15 & $4356.38 \pm 14.72 \mathrm{de}$ & $4691.64 \pm 15.75 \mathrm{de}$ & $4667.69 \pm 7.55 \mathrm{de}$ & $4970.18 \pm 8.84 b c$ & $4671.47 \pm 250.95 \mathrm{~B}$ \\
\hline & 20 & $4158.28 \pm 5.93 \mathrm{~h}$ & $4491.16 \pm 4.75$ ef & $4682.32 \pm 7.84$ de & $4792.81 \pm 12.70 \mathrm{~cd}$ & $4531.14 \pm 278.06 \mathrm{C}$ \\
\hline & Mean & $4278.72 \pm 160.42 \mathrm{C}$ & $4467.05 \pm 150.16 \mathrm{~B}$ & $4566.91 \pm 196.91 \mathrm{~B}$ & $4967.36 \pm 394.71 \mathrm{~A}$ & \\
\hline \multirow{6}{*}{$p$} & 0 & $3040.76 \pm 6.77 \mathrm{~g}$ & $3169.06 \pm 27.58 \mathrm{de}$ & $3372.95 \pm 19.87 \mathrm{c}$ & $3420.17 \pm 18.04 b$ & $3250.73 \pm 177.39 \mathrm{E}$ \\
\hline & 5 & $3303.52 \pm 10.17 \mathrm{fg}$ & $3445.92 \pm 13.33 \mathrm{de}$ & $3759.75 \pm 27.59 c$ & $4025.80 \pm 3.84 \mathrm{ab}$ & $3633.75 \pm 323.48 \mathrm{~B}$ \\
\hline & 10 & $3408.00 \pm 34.40 \mathrm{def}$ & $3503.58 \pm 3.79 \mathrm{~d}$ & $3777.04 \pm 8.00 \mathrm{c}$ & $4133.48 \pm 26.59 \mathrm{a}$ & $3705.52 \pm 325.35 \mathrm{~A}$ \\
\hline & 15 & $3339.92 \pm 3.55$ efg & $3417.17 \pm 17.14 \mathrm{de}$ & $3447.11 \pm 20.89 \mathrm{de}$ & $3409.72 \pm 5.96$ def & $3403.48 \pm 45.35 \mathrm{C}$ \\
\hline & 20 & $3002.72 \pm 20.91 \mathrm{~h}$ & $3392.79 \pm 3.18$ def & $3430.98 \pm 2.57 \mathrm{de}$ & $3432.94 \pm 16.72 \mathrm{~g}$ & $3314.86 \pm 208.91 \mathrm{D}$ \\
\hline & Mean & $3218.98 \pm 184.41 \mathrm{D}$ & $3385.70 \pm 127.96 \mathrm{C}$ & $3557.57 \pm 194.52 \mathrm{~B}$ & $3684.42 \pm 362.88 \mathrm{~A}$ & \\
\hline \multirow{6}{*}{$\mathrm{Ca}$} & 0 & $174.74 \pm 9.85 \mathrm{fg}$ & $203.38 \pm 26.97 \mathrm{~b}-\mathrm{f}$ & $188.53 \pm 3.42 \mathrm{~d}-\mathrm{g}$ & $192.88 \pm 18.50 \mathrm{c}-\mathrm{f}$ & $189.88 \pm 11.86 \mathrm{D}$ \\
\hline & 5 & $214.80 \pm 2.78 \mathrm{a}-\mathrm{e}$ & $183.90 \pm 35.97 \mathrm{e}-\mathrm{g}$ & $184.22 \pm 6.78 \mathrm{e}-\mathrm{g}$ & $216.45 \pm 2.01 \mathrm{a}-\mathrm{e}$ & $199.84 \pm 18.24 \mathrm{CD}$ \\
\hline & 10 & $207.54 \pm 15.38 \mathrm{~b}-\mathrm{f}$ & $238.10 \pm 7.50 \mathrm{ab}$ & $231.02 \pm 4.68 \mathrm{ab}$ & $247.60 \pm 5.06 \mathrm{a}$ & $231.07 \pm 17.09 \mathrm{~A}$ \\
\hline & 15 & $247.99 \pm 9.47 \mathrm{a}$ & $215.33 \pm 4.62 \mathrm{a}-\mathrm{e}$ & $223.38 \pm 3.17 \mathrm{a}-\mathrm{d}$ & $214.06 \pm 6.77 \mathrm{a}-\mathrm{e}$ & $225.19 \pm 15.75 \mathrm{AB}$ \\
\hline & 20 & $155.15 \pm 6.50 \mathrm{~g}$ & $228.67 \pm 19.91 \mathrm{a}-\mathrm{c}$ & $237.99 \pm 6.47 \mathrm{ab}$ & $224.64 \pm 12.82 \mathrm{a}-\mathrm{c}$ & $211.61 \pm 38.05 \mathrm{BC}$ \\
\hline & Mean & $200.05 \pm 36.15$ B & $213.88 \pm 21.31 \mathrm{~A}$ & $213.03 \pm 24.92 \mathrm{~A}$ & $219.13 \pm 19.77 \mathrm{~A}$ & \\
\hline \multirow{6}{*}{$\mathrm{Mg}$} & 0 & $1450.85 \pm 2.90 \mathrm{~g}-\mathrm{j}$ & $1451.42 \pm 1.68 \mathrm{f}-\mathrm{j}$ & $1427.95 \pm 1.14 \mathrm{~h}-\mathrm{j}$ & $1498.09 \pm 6.10 \mathrm{a}-\mathrm{h}$ & $1457.08 \pm 29.45 \mathrm{~B}$ \\
\hline & 5 & $1444.91 \pm 0.64 \mathrm{e}-\mathrm{j}$ & $1468.45 \pm 1.06 \mathrm{~d}-\mathrm{j}$ & $1408.16 \pm 4.79 \mathrm{ij}$ & $1520.55 \pm 1.37 \mathrm{a}-\mathrm{g}$ & $1460.52 \pm 47.09 \mathrm{~B}$ \\
\hline & 10 & $1495.67 \pm 8.03 \mathrm{a}-\mathrm{i}$ & $1529.55 \pm 3.52 \mathrm{a}-\mathrm{f}$ & $1571.94 \pm 1.63 \mathrm{ab}$ & $1582.05 \pm 1.50 \mathrm{a}$ & $1544.80 \pm 39.96 \mathrm{~A}$ \\
\hline & 15 & $1447.88 \pm 3.32 \mathrm{f}-\mathrm{j}$ & $1491.46 \pm 0.91 \mathrm{~b}-\mathrm{i}$ & $1546.84 \pm 6.09$ a-d & $1550.61 \pm 1.28 \mathrm{a}-\mathrm{c}$ & $1509.20 \pm 49.01 \mathrm{AB}$ \\
\hline & 20 & $1394.71 \pm 2.56 j$ & $1482.04 \pm 2.54 \mathrm{c}-\mathrm{i}$ & $1542.31 \pm 0.88 \mathrm{a}-\mathrm{e}$ & $1560.89 \pm 13.31 \mathrm{a}-\mathrm{c}$ & $1494.99 \pm 74.85 \mathrm{AB}$ \\
\hline & Mean & $1446.81 \pm 35.79 \mathrm{C}$ & $1484.58 \pm 29.05 \mathrm{BC}$ & $1499.44 \pm 75.47 \mathrm{AB}$ & $1542.44 \pm 33.25 \mathrm{~A}$ & \\
\hline
\end{tabular}

Different $B C$ treatments and $N$ levels significantly $(p \leq 0.05)$ affected the $\mathrm{Mg}$ content of maize grain (Table 5). The interaction effect of $\mathrm{BC}$ and $\mathrm{N}$ levels was found to be significant $(p>0.05)$. The mean values of the data indicated that BC applied at $10 \mathrm{tha}^{-1}$ generated the highest average $\mathrm{Mg}$ content of $1544.80 \pm 39.96 \mathrm{mg} \mathrm{kg}^{-1}$ in maize grain, which was followed by $15 \mathrm{t} \mathrm{ha}^{-1}$ that yielded $1509.20 \pm 49.01 \mathrm{mg} \mathrm{kg}^{-1} \mathrm{Mg}$ content. The average $\mathrm{Mg}$ content of maize grain was the lowest $\left(1457.08 \pm 29.45 \mathrm{mg} \mathrm{kg}^{-1}\right)$ without BC. Among the different $\mathrm{N}$ levels, the $\mathrm{Mg}$ content in maize grain was the highest $\left(1542.44 \pm 33.25 \mathrm{mg} \mathrm{kg}^{-1}\right)$ with the $\mathrm{N}$ application at $200 \mathrm{~kg} \mathrm{ha}^{-1}$, and the lowest $\left(1446.81 \pm 35.79 \mathrm{mg} \mathrm{kg}^{-1}\right)$ in plots without the application of $\mathrm{N}$.

\subsection{Effect of Biochar and Nitrogen Application on Micronutrients in Maize Grain}

We found significant individual effects of the $\mathrm{BC}$ and $\mathrm{N}$ levels $(p \leq 0.05$; Table 6$)$ on the grain $\mathrm{Zn}$ content. However, the interaction of $\mathrm{BC}$ and $\mathrm{N}$ was revealed to be non-significant $(p>0.05)$. The mean values of the data showed that no application of BC resulted in the highest grain $\mathrm{Zn}$ content $\sim 26.01 \pm 1.06 \mathrm{mg} \mathrm{kg}^{-1}$. The grain average $\mathrm{Zn}$ content was lowest $\left(23.19 \pm 1.43 \mathrm{mg} \mathrm{kg}^{-1}\right)$ with the application of $20 \mathrm{t} \mathrm{ha}^{-1} \mathrm{BC}$. The grain $\mathrm{Zn}$ content increased consistently with increasing $\mathrm{N}$ levels. The highest average grain $\mathrm{Zn}$ content $\left(25.06 \pm 1.68 \mathrm{mg} \mathrm{kg}^{-1}\right)$ was observed when $200 \mathrm{~kg} \mathrm{~N} \mathrm{ha}^{-1}$ was added. The Zn content of the grains was the lowest $\left(22.71 \pm 1.04 \mathrm{mg} \mathrm{kg}^{-1}\right)$ without $\mathrm{N}$ (Table 6, Figure 1).

The Fe content of maize grain ranged from $24.5 \pm 0.98 \mathrm{mg} \mathrm{kg}^{-1}$ (at $20 \mathrm{t} \mathrm{ha}^{-1} \mathrm{BC}$ without $\mathrm{N}$ ) to $33.10 \pm 0.98 \mathrm{mg} \mathrm{kg}^{-1}$ (without $\mathrm{BC}$ and $150 \mathrm{~kg} \mathrm{ha}^{-1} \mathrm{~N}$ ). An analysis of variance of data showed that the individual and combined effects of $\mathrm{BC}$ and $\mathrm{N}$ were significant $(p>0.05$; Table 6$)$ on the Fe content. The Fe content steadily increased with increasing $\mathrm{N}$ levels. On the contrary, an increasing level of $\mathrm{BC}$ adversely affected the Fe content of maize grain. The mean values indicated that maize grain had maximum $\mathrm{Fe}$ content $\left(32.28 \pm 1.16 \mathrm{mg} \mathrm{kg}^{-1}\right)$ in those plots that were treated with no BC. Plots treated 
with $20 \mathrm{tha}^{-1}$ of BC showed the minimum amount of Fe content $\left(27.83 \pm 2.27 \mathrm{mg} \mathrm{kg}^{-1}\right)$ in the grain.

The $\mathrm{Cu}$ content in maize grain showed the significant influence of $\mathrm{BC}, \mathrm{N}$, and $\mathrm{BC} \times \mathrm{N}$ interaction. Maize grain's $\mathrm{Cu}$ content significantly $(p<0.05$; Table 6$)$ decreased with $\mathrm{BC}$. Among different levels of $\mathrm{BC}$, the highest average grain $\mathrm{Cu}$ content $\left(2.87 \pm 0.42 \mathrm{mg} \mathrm{kg}^{-1}\right)$ was examined without $\mathrm{BC}$, which was followed by $5 \mathrm{t} \mathrm{ha}^{-1}$. The plots that received $20 \mathrm{tha}^{-1} \mathrm{BC}$ showed minimal Cu content $\left(2.52 \pm 0.51 \mathrm{mg} \mathrm{kg}^{-1}\right)$ in the grains. Regarding the $\mathrm{N}$ levels, a constant increase in the grain $\mathrm{Cu}$ content of maize was recorded. The highest grain $\mathrm{Cu}$ content of $2.83 \pm 0.31 \mathrm{mg} \mathrm{kg} \mathrm{kg}^{-1}$ was recorded with the addition of $200 \mathrm{~kg} \mathrm{~N} \mathrm{ha}^{-1}$. The grain Cu content was lowest $\left(2.51 \pm 0.28 \mathrm{mg} \mathrm{kg}^{-1}\right)$ without $\mathrm{N}$. The interaction of $\mathrm{BC}$ and $\mathrm{N}$ levels revealed that the highest grain $\mathrm{Cu}$ content $\left(3.30 \pm 0.17 \mathrm{mg} \mathrm{kg}^{-1}\right)$ was found with no $\mathrm{BC}$ along with $100 \mathrm{~kg} \mathrm{~N} \mathrm{ha}^{-1}$ and the grain $\mathrm{Cu}$ content was lowest $\left(2.06 \pm 0.02 \mathrm{mg} \mathrm{kg}^{-1}\right)$ with $20 \mathrm{tha}^{-1}$ of BC without $\mathrm{N}$.
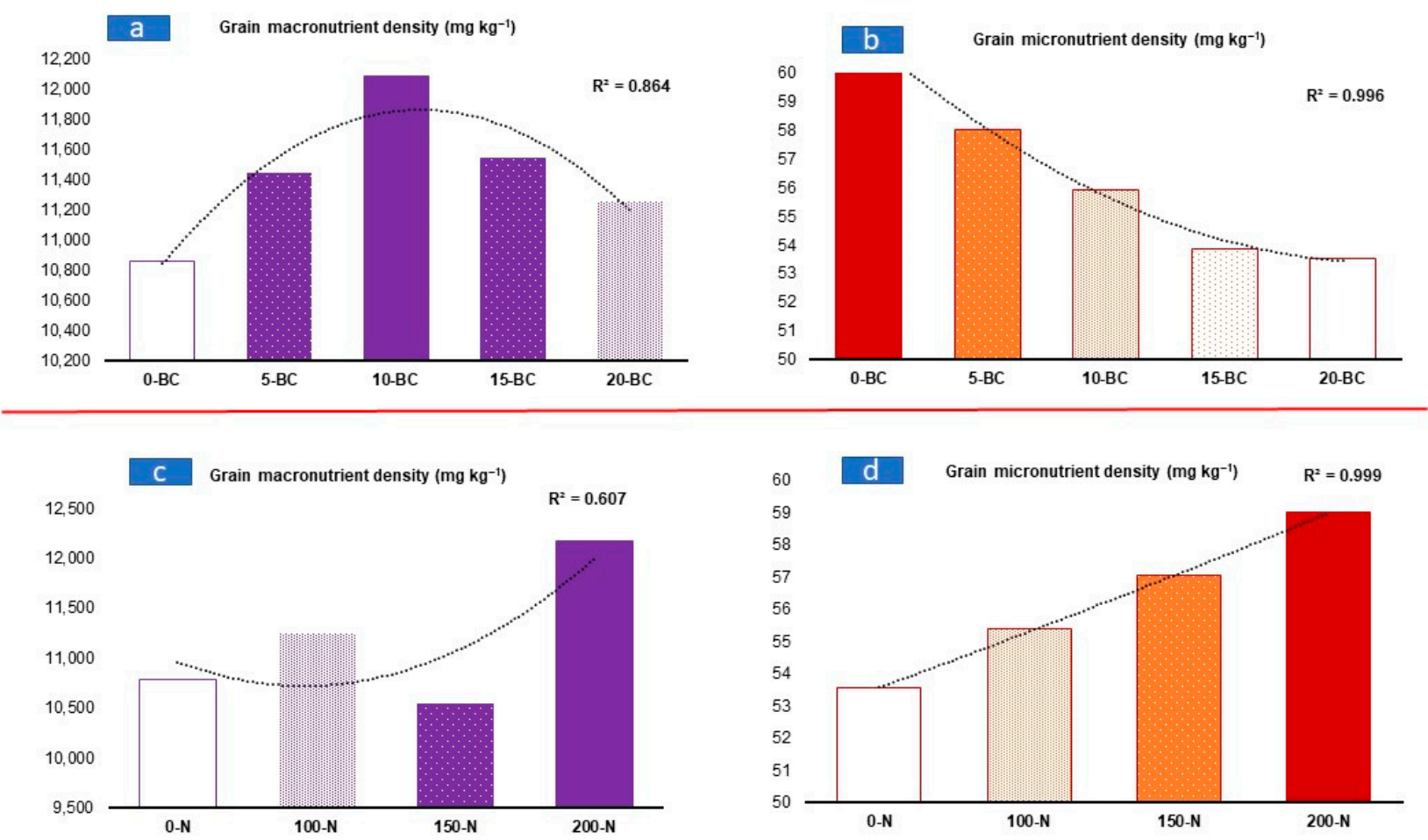

Figure 1. Effect of biochar (BC) (averaged across nitrogen $(\mathrm{N})$ levels), and N (averaged across BC levels) on the maize grain density of macro- and micronutrients. A polynomial regression (second degree) was employed to visually reflect the impact of $\mathrm{BC}$ and $\mathrm{N}$. BC was applied at the rates of 5 (5-BC), 10 (10-BC), 15 (15-BC), and $20 \mathrm{t} \mathrm{ha}^{-1}$ (20-BC) and $\mathrm{N}$ at $100(100-\mathrm{N}), 150(150-\mathrm{N})$, and $200 \mathrm{~kg} \mathrm{ha}^{-1}(200-\mathrm{N})$ along with control (without BC and N) in a split-plot arrangement using a randomized complete block design. The macronutrient grain density is the sum of potassium (K), phosphorus $(\mathrm{P})$, calcium $(\mathrm{Ca})$, and magnesium $(\mathrm{Mg})$. The micronutrient grain density represents the sum of zinc $(\mathrm{Zn})$, iron $(\mathrm{Fe})$, and copper $(\mathrm{Cu})$ contents. Clearly, the micro-element grain density was decreased with an increased level of BC as compared to the control (without BC and N) (b). An increased $\mathrm{N}$ level elevated the micronutrient grain density (d). However, the macronutrient grain density was maximum at $10-\mathrm{BC}$ followed by $5-\mathrm{BC}=15-\mathrm{BC}>20-\mathrm{BC}$ and control (a). The maximum macronutrient grain density was found at $200-\mathrm{N}$ followed by $100-\mathrm{N}$, control, and at $150-\mathrm{N}$ (c). 
Table 6. Micro-elements' concentration of maize grains $\left(\mathrm{mg} \mathrm{kg}^{-1}\right)$ as affected by different biochar $(\mathrm{BC})$ and nitrogen $(\mathrm{N})$ levels.

\begin{tabular}{|c|c|c|c|c|c|c|}
\hline \multirow{2}{*}{ Element } & \multirow{2}{*}{ Biochar (t ha-1) } & \multicolumn{4}{|c|}{ Nitrogen $\left(\mathrm{kg} \mathrm{ha}^{-1}\right)$} & \multirow{2}{*}{ Means } \\
\hline & & 0 & 100 & 150 & 200 & \\
\hline \multirow{6}{*}{$\mathrm{Zn}$} & 0 & $24.53 \pm 0.29 \mathrm{~b}-\mathrm{f}$ & $26.12 \pm 1.62 \mathrm{ab}$ & $27.03 \pm 0.16 \mathrm{a}$ & $26.36 \pm 0.37 \mathrm{ab}$ & $26.01 \pm 1.06 \mathrm{~A}$ \\
\hline & 5 & $22.30 \pm 0.44 \mathrm{fg}$ & $23.13 \pm 0.70 \mathrm{de}-\mathrm{g}$ & $25.29 \pm 0.94 \mathrm{a}-\mathrm{d}$ & $26.98 \pm 0.17 \mathrm{a}$ & $24.43 \pm 2.12 \mathrm{~B}$ \\
\hline & 10 & $22.12 \pm 0.38 \mathrm{fg}$ & $22.91 \pm 0.23 \mathrm{~d}-\mathrm{g}$ & $25.80 \pm 0.08 \mathrm{a}-\mathrm{c}$ & $22.73 \pm 6.03 \mathrm{e}-\mathrm{g}$ & $23.39 \pm 1.64 \mathrm{~B}$ \\
\hline & 15 & $22.61 \pm 0.51 \mathrm{e}-\mathrm{g}$ & $23.45 \pm 0.29 \mathrm{c}-\mathrm{g}$ & $22.69 \pm 0.18 c-g$ & $24.41 \pm 0.35 \mathrm{~b}-\mathrm{g}$ & $23.29 \pm 0.84 \mathrm{~B}$ \\
\hline & 20 & $22.01 \pm 0.37 \mathrm{~g}$ & $21.98 \pm 0.37 \mathrm{~g}$ & $23.96 \pm 0.12 \mathrm{~b}-\mathrm{g}$ & $24.84 \pm 0.54 \mathrm{a}-\mathrm{e}$ & $23.19 \pm 1.43 \mathrm{~B}$ \\
\hline & Mean & $22.71 \pm 1.04 \mathrm{~B}$ & $23.52 \pm 1.55 \mathrm{~B}$ & $24.95 \pm 1.68 \mathrm{~A}$ & $25.06 \pm 1.68 \mathrm{~A}$ & \\
\hline \multirow{6}{*}{$\mathrm{Fe}$} & 0 & $30.57 \pm 0.67 \mathrm{~b}-\mathrm{f}$ & $32.51 \pm 0.62 \mathrm{ab}$ & $33.10 \pm 0.98 \mathrm{a}$ & $32.92 \pm 0.20 \mathrm{a}$ & $32.28 \pm 1.16 \mathrm{~A}$ \\
\hline & 5 & $30.66 \pm 0.67 \mathrm{~b}-\mathrm{e}$ & $30.94 \pm 0.52 \mathrm{a}-\mathrm{d}$ & $31.13 \pm 0.57 \mathrm{a}-\mathrm{c}$ & $30.25 \pm 0.70 \mathrm{c}-\mathrm{f}$ & $30.75 \pm 0.38 \mathrm{~B}$ \\
\hline & 10 & $28.58 \pm 0.77 \mathrm{e}-\mathrm{h}$ & $28.65 \pm 3.03 \mathrm{e}-\mathrm{h}$ & $31.35 \pm 3.85 \mathrm{a}-\mathrm{c}$ & $31.22 \pm 1.15 \mathrm{a}-\mathrm{c}$ & $29.95 \pm 1.54 \mathrm{C}$ \\
\hline & 15 & $27.33 \pm 0.56 \mathrm{hi}$ & $25.80 \pm 0.70 \mathrm{ij}$ & $27.56 \pm 1.54 \mathrm{~g}-\mathrm{i}$ & $31.63 \pm 0.74 \mathrm{a}-\mathrm{c}$ & $28.08 \pm 2.49 \mathrm{D}$ \\
\hline & 20 & $24.49 \pm 0.98 \mathrm{j}$ & $28.43 \pm 0.92 \mathrm{f}-\mathrm{h}$ & $28.82 \pm 0.68 \mathrm{~d}-\mathrm{h}$ & $29.57 \pm 0.26 \mathrm{c}-\mathrm{g}$ & $27.83 \pm 2.27 \mathrm{D}$ \\
\hline & Mean & $28.33 \pm 2.56 \mathrm{~B}$ & $29.27 \pm 2.57 \mathrm{~B}$ & $30.39 \pm 2.19 \mathrm{~A}$ & $31.12 \pm 1.29 \mathrm{~A}$ & \\
\hline \multirow{6}{*}{$\mathrm{Cu}$} & 0 & $2.80 \pm 0.58 \mathrm{~d}-\mathrm{f}$ & $3.30 \pm 0.17 \mathrm{a}$ & $3.06 \pm 0.03 \mathrm{a}-\mathrm{c}$ & $2.32 \pm 0.04 \mathrm{hi}$ & $2.87 \pm 0.42 \mathrm{~A}$ \\
\hline & 5 & $2.67 \pm 0.24 \mathrm{e}-\mathrm{g}$ & $2.64 \pm 0.05 \mathrm{fg}$ & $3.15 \pm 0.03 \mathrm{ab}$ & $2.90 \pm 0.05 \mathrm{~b}-\mathrm{e}$ & $2.84 \pm 0.24 \mathrm{~A}$ \\
\hline & 10 & $2.49 \pm 0.12 \mathrm{gh}$ & $2.69 \pm 0.02 \mathrm{~d}-\mathrm{g}$ & $2.26 \pm 0.03 \mathrm{hi}$ & $2.95 \pm 0.10 \mathrm{~b}-\mathrm{d}$ & $2.60 \pm 0.29 \mathrm{~B}$ \\
\hline & 15 & $2.51 \pm 0.11 \mathrm{gh}$ & $2.17 \pm 0.004 \mathrm{i}^{\circ}$ & $2.51 \pm 0.01 \mathrm{gh}$ & $2.84 \pm 0.11 \mathrm{c}-\mathrm{f}$ & $2.51 \pm 0.27 \mathrm{~B}$ \\
\hline & 20 & $2.06 \pm 0.02 \mathrm{i}$ & $2.16 \pm 0.03 \mathrm{i}$ & $2.70 \pm 0.07 \mathrm{~d}-\mathrm{g}$ & $3.16 \pm 0.01 \mathrm{ab}$ & $2.52 \pm 0.51 \mathrm{~B}$ \\
\hline & Mean & $2.51 \pm 0.28 \mathrm{~B}$ & $2.59 \pm 0.47 \mathrm{~B}$ & $2.74 \pm 0.37 \mathrm{~A}$ & $2.83 \pm 0.31 \mathrm{~A}$ & \\
\hline
\end{tabular}

Means in each category followed by different letters are significantly different at $p<0.05$.

\section{Discussion}

\subsection{Effect of Biochar and Nitrogen Application on Macronutrients ( $P, K, C a$, and $\mathrm{Mg}$ ) in Maize Grain}

We found partial support for the first hypothesis. Both the individual and interactive effects of $\mathrm{BC}$ and $\mathrm{N}$ applications had a synergistic effect on macronutrients $(\mathrm{K}, \mathrm{P}, \mathrm{Ca}$, $\mathrm{Mg}$ ). The $\mathrm{P}$ content of maize grain significantly increased with $\mathrm{BC}$ application up to $10 \mathrm{tha}^{-1}$ along with the $\mathrm{N}$ application. Dharmakeerthi et al. [25] reported similar findings where the BC application increased P uptake compared with the control. The increased $\mathrm{P}$ concentration in maize grain with the $\mathrm{BC}$ application might be due to $\mathrm{BC}$-induced changes in soil-available $\mathrm{P}$ and plant $\mathrm{P}$ uptake that could be driven by a suite of factors involved in the soil's physical and chemical reactions, and plant growth. A recent metaanalysis of $\mathrm{P}$ dynamics in soils and plant systems under the $\mathrm{BC}$ application on acidic $(\mathrm{pH} \leq 6.5)$ and neutral/alkaline $(\mathrm{pH}>6.5)$ soils further supports our argument [26]. Nevertheless, the relative more pronounced effect of the $\mathrm{BC}$ application has been reported in acidic soils as compared to the high $\mathrm{pH}$ soils. The stimulation of the mycorrhizal species with the application of $\mathrm{BC}$ that may have changed the soil N/P ratio [27] could also be one of the plausible explanations. As we did not investigate the mycorrhizal effect, the stimulation of the mycorrhizal species seems irrelevant to our study. In addition, $\mathrm{N}$ further may have promoted $\mathrm{P}$ uptake by increasing the rate of metabolism, root density, $\mathrm{P}$ solubility, and its availability by decreasing the soil $\mathrm{pH}$ through the absorption of $\mathrm{NH}_{4}$ [28]. The application of $\mathrm{BC}$ might have increased enzyme activities and improved several microbial groups' biomass which suggested a selection pressure of BC to the soil microbial population and induced significantly higher root mass. Similar results were reported by Kocsis et al. [29] where the BC application was effective (in terms of maize yield) on weakly humus sandy soils.

An elevated $\mathrm{K}$ content in maize grain with an increasing $\mathrm{BC}$ level was maximum at the application rate of $10 \mathrm{tha}^{-1}$. Similarly, the $\mathrm{K}$ content in grain increased steadily with increasing $\mathrm{N}$ levels. The accelerated $\mathrm{K}$ uptake by maize with the application of $\mathrm{BC}$ may be attributed to the $\mathrm{BC}$-mediated increased availability of $\mathrm{BC}$-containing soluble $\mathrm{K}$ that may have impacted its accumulation in grains [30]. Likewise, the significant increase in $\mathrm{K}$ uptake with the $\mathrm{N}$ application over the control without $\mathrm{N}$ was consistent with the reports by Shehu et al. [31]. Although ammonium $\mathrm{N}$ from urea strived for the uptake of cation 
such as K and decreased its availability, the application of urea coupled with BC may have depleted exchangeable and non-exchangeable pools of soil $\mathrm{K}$ that enhanced the uptake of $\mathrm{K}$ [32].

A significant increase in the Ca content was observed with BC. However, the N application did not significantly (statistically non-significant) affect the Ca content. This divergence might be due to the accelerated nutrients' availability and enhanced nutrient use efficiency through the nutrients' retention, modifying soil microbial dynamics, and thereby the increased decomposition of SOM may have occurred [33]. Dharmakeerthi et al. [25] reported similar results that the $\mathrm{BC}$ application increased the uptake of $\mathrm{Ca}$ as compared to the control (without BC). Correspondingly, the application of $\mathrm{N}$ enhanced plant nutrients' availability and uptake ability in the soil. The increased application of the $\mathrm{N}$ fertilizer enhanced nutrients' uptake response to promote various cellular functions of the plants [34].

The application of $\mathrm{BC}$ and $\mathrm{N}$ alone and in combination significantly affected the $\mathrm{Mg}$ content of maize grain. The highest individual effect of $\mathrm{BC}$ was observed at an application rate of $10 \mathrm{t} \mathrm{ha}^{-1}$ which then decreased with increasing levels of $\mathrm{BC}$. However, the $\mathrm{Mg}$ content steadily increased with increasing $\mathrm{N}$ levels. The present results are consistent with the findings of Dharmakeerthi et al. [25], who reported that the BC application increased the uptake of $\mathrm{Mg}$ as compared to the control (without the application of $\mathrm{BC}$ ). The optimum level of BC may have reduced the leaching losses of the nutrients (as evident by the relative accrual in SOM at the reproductive stage of maize) and made the nutrients available to the crop. In addition, the $\mathrm{N}$ application synergistically enhanced the uptake of $\mathrm{Mg}$ [35]. Esmaili et al. [36] also reported increased $\mathrm{Mg}$ concentration due to the $\mathrm{N}$-induced exchange capacity of roots and subsequent uptake of bivalent cations.

\subsection{Effect of Biochar and Nitrogen Application on Micronutrients ( $\mathrm{Zn}, \mathrm{Fe}$, and $\mathrm{Cu})$ in Maize Grain}

The micronutrients viz. Zn, Fe, and $\mathrm{Cu}$ of maize grain were also significantly affected by BC and N applications. BC application adversely affected the Fe content of the grain, whereas a positive relation existed between the grain Fe content and $\mathrm{N}$ application. The decrease in the Fe content of grain with the BC application might be due to the precipitation of Fe that lowered its mobility into the phloem cells for long distance translocation [37]. Soil $\mathrm{OM}$ is known to bind more $\mathrm{Zn}$, and $\mathrm{Cu}$ compared to Fe because of the lower sensitivity to redox changes. The fertilizer application methods and cropping sequences are responsible for the variation in the behavior of $\mathrm{Zn}, \mathrm{Fe}$, and $\mathrm{Cu}$ in the soil and plant systems. The availability of $\mathrm{Zn}, \mathrm{Cu}$, and Fe in the soil, as well as their concentrations in different crops, can be improved by applying N, P, and K fertilizers [38]. In alkaline soils, the higher uptake of $\mathrm{Zn}, \mathrm{Cu}$, and Fe was usually associated with the increased application of the $\mathrm{N}$ fertilizer. On the other hand, the Fe content of the grain was steadily increased with the increasing level of $\mathrm{N}$. This potential argument against such elevated levels could be due to (i) the flush in the microbial activities such as sulfur oxidation by bacteria, which may have reduced soil pH; and (ii) the production of organic acids and mineralization of SOM [39]. A similar trend of results was noted for the grain $\mathrm{Cu}$ and $\mathrm{Zn}$ contents in maize. We contend that $\mathrm{BC}$, being a porous material, may have adsorbed the available $\mathrm{Cu}$ and $\mathrm{Zn}$ cations that resulted in the reduced $\mathrm{Cu}$ and $\mathrm{Zn}$ availability to the plants. The present results were supported by previous literature [40]. Considering the severity of malnutrition in terms of micronutrients in Pakistan, and the vital roles of $\mathrm{Zn}$ and $\mathrm{Cu}$, the $\mathrm{BC}$ loading with specific micronutrients could be one of the options to improve the maize grain quality. On the contrary, the grain $\mathrm{Cu}$ and $\mathrm{Zn}$ contents increased with increasing $\mathrm{N}$ levels. This might be due to the root to shoot movement of $\mathrm{Cu}$ and $\mathrm{Zn}$ in the xylem and re-translocation in the plant's phloem that was facilitated by endogenous chelators such as nicotinamine and 2-deoxymugineic acid (synthesized from methionine) and were thus dependent on $\mathrm{N}$ nutrition [41]. Similarly, a high N supply (higher level) may have increased the production of phytosiderophores, which may have indirectly regulated Zn mobility and enhanced its accumulation in grain [42]. 
Raw biochar is reported to have usually a higher payback time, even with increased crop yields [43]. Moreover, $\mathrm{BC}$ with $\mathrm{pH}>7.5$ is discouraged to apply on alkaline calcareous soils (common in semi-arid to arid environments). Overall, the $\mathrm{pH}$ of $\mathrm{BC}$ used in our experiment ranged between 6.46 and 6.50 (largely uncommon compared to most of the $\mathrm{BC}$ available in the local market). The argument against the comparative accrual in the SOM at the reproductive stage rather than in soil after harvesting dictates the role of the labile pool of $\mathrm{BC}$ in the presence of a relatively exhaustive test crop (maize). At that time (reproductive stage), the plant was actively photosynthesizing, and the labile pool of BC was not preferred. However, after the reproductive stage when the photosynthesis was almost stopped and photosynthates may have been stored, metabolically available organic $\mathrm{C}$ from the labile pool of BC was preferably consumed, and thus low SOM was found (Table 3). Nevertheless, there is a need to investigate the impact of aged BC on the quality of maize grain, SOM storage potential on soils with different OM contents, soil textures, and clay mineralogy. Clay minerals are the most reactive inorganic components of soils, largely govern soil properties and functions, and may mask the true potential of BC due to organo-mineral interactions. If acacia prunings-derived $\mathrm{BC}$ is to be made part of the land management system, no acidification but rather cost-effective micronutrient enrichment techniques have to be further explored.

\section{Conclusions}

The application of $\mathrm{BC}$ and $\mathrm{N}$, individually and interactively, affected the mineral contents of maize grains. BC application at $10 \mathrm{tha}^{-1}$ significantly $(p<0.05)$ improved the macro-mineral contents $(\mathrm{K}, \mathrm{P}, \mathrm{Ca}$, and $\mathrm{Mg})$. On the other hand, BC application at $20 \mathrm{tha}^{-1}$ reduced the contents of micro-minerals $(\mathrm{Zn}, \mathrm{Fe}, \mathrm{Cu})$ in maize grain. The application of $\mathrm{N}$ at $200 \mathrm{~kg} \mathrm{ha}{ }^{-1}$ increased the macro- and micro-minerals ( $\mathrm{Zn}, \mathrm{Fe}, \mathrm{Cu}$ ) of maize grain. It was concluded that the integrated use of $\mathrm{BC}$ and $\mathrm{N}$ could be a valuable strategy to improve the nutritional quality of maize grains. Micronutrients' loading with $\mathrm{BC}$ is recommended to achieve the desired concentration of micro-minerals in maize grain. Further investigation is warranted to validate the impact of BC made of different feedstocks (other than the prunings of Acacia nilotica and especially of the feedstock available in bulk to promote a circular economy) on contrasting soil types (other than sandy loam).

Author Contributions: S.A. designed the research. H.U. conducted the experiment. S.A. and Y.H. supervised the research experiment. W.A. and M.S. provided help and advice in manuscript preparation. S.M. provided help in laboratory analyses. All authors contributed to editorial changes in the manuscript. All authors have read and agreed to the published version of the manuscript.

Funding: We acknowledge the Higher Education Commission (HEC) of Pakistan for the financial support to complete this study.

Institutional Review Board Statement: Not applicable.

Informed Consent Statement: Not applicable.

Data Availability Statement: Data presented in this study are available on request from the corresponding author.

Acknowledgments: We acknowledge the Higher Education Commission (HEC) of Pakistan for the financial support under the International Research Support Initiative Program (IRSIP), and the School of Chemical Sciences, University of Auckland, New Zealand for facilitating the laboratory analysis for this study. The need for this manuscript partially emerged during the Food and Agriculture Organization of the United Nations project (FAO; Project Reference, GCP/PAK/143/USA, "4R Nutrient Stewardship for Sustainable Agriculture Intensification in Pakistan: Baseline Input Atlas and Promotion of Best Soil Management Practices"). WA is thankful to Khalid Mahmood (Rothamsted Research, United Kingdom) and Hana'a Burezq and Shabbir A. Shahid (Desert Agriculture and Ecosystems Program, Environment and Life Sciences Research Center, Kuwait Institute for Scientific Research, Kuwait) for the thought-provoking discussions on how to tailor the properties of biochar and devise technology packages for small, medium, and large-scale growers of semi-arid and arid 
regions. The authors are thankful to three anonymous reviewers for their comments and suggestions to improve the quality of this manuscript. All the views expressed in this manuscript are the authors' own views and do not necessarily reflect the opinion of their respective organizations.

Conflicts of Interest: There is no conflict of interest.

\section{References}

1. Díaz-Gómez, J.L.; Castorena-Torres, F.; Preciado-Ortiz, R.E.; García-Lara, S. Anti-cancer activity of maize bioactive peptides. Front. Chem. 2017, 5, 44. [CrossRef] [PubMed]

2. Nuss, E.T.; Tanumihardjo, S.A. Maize: A paramount staple crop in the context of global nutrition. Comp. Rev. Food Sci. Food Safe 2010, 9, 417-436. [CrossRef] [PubMed]

3. Trautvetter, U.; Jahreis, G.; Kiehntopf, M.; Glei, M. Consequences of a high phosphorus intake on mineral metabolism and bone remodeling in dependence of calcium intake in healthy subjects-A randomized placebo-controlled human intervention study. Nutr. J. 2016, 15, 7. [CrossRef] [PubMed]

4. Roumelioti, M.E.; Glew, R.H.; Khitan, Z.J.; Rondon-Berrios, H.; Argyropoulos, C.P.; Malhotra, D.; Tzamaloukas, A.H. Fluid balance concepts in medicine: Principles and practice. World J. Nephrol. 2018, 7, 1-28. [CrossRef] [PubMed]

5. Grober, U.; Schmidt, J.; Kisters, K. Magnesium in prevention and therapy. Nutrients 2015, 7, 8199-8226. [CrossRef]

6. Al Alawi, A.M.; Majoni, S.W.; Falhammar, H. Magnesium and Human Health: Perspectives and Research Directions. Int. J. Endocrinol. 2018, 2018, 9041694. [CrossRef]

7. Ahmad, K.; Ijaz, A.B.; Muneer, M.; Munawar, I.; Zafar, I. Removal of heavy metals ( $\mathrm{Zn}, \mathrm{Cr}, \mathrm{Pb}, \mathrm{Cd}, \mathrm{Cu}$ and Fe) in aqueous media by calcium carbonate as an adsorbent. Int. J. Chem. Biol. Sci. 2012, 2, 48-53.

8. Abbaspour, N.; Hurrell, R.; Kelishadi, R. Review on iron and its importance for human health. J. Res. Med. Sci. 2014, 19, 164-174.

9. Ministry of National Health Services Regulation and Coordination (MoNHSR\&C) GoP. National Nutrition Survey; MoNHSR\&C: Islamabad, Pakistan, 2018.

10. NFDC (National Fertilizer Development Centre). Soil Fertility and Inputs Use Atlas of Pakistan: The Khyber Pakhtunkhwa Province; Ahmad, W., Khan, M.J., Mustafa, Z., Mahmood, K., Singh, B., Zia, M.H., Ali, A., Jalil, A., Eds.; NFDC (National Fertilizer Development Centre): Islamabad, Pakistan, 2018; p. 115, ISBN 0978-969-78888-00-9.

11. Baig-Ansari, N.; Badruddin, S.H.; Karmaliani, R.; Harris, H.; Jehan, I.; Pasha, O. Anemia prevalence and risk factors in pregnant women in an urban area of Pakistan. Food Nutr. Bull. 2008, 29, 132-139. [CrossRef]

12. Parks, S.; Hoffman, M.K.; Goudar, S.S.; Patel, A.; Saleem, S.; Ali, S.A. Maternal anaemia and maternal, fetal, and neonatal outcomes in a prospective cohort study in India and Pakistan. BJOG Int. J. Obs. Gynaecol. 2019, 126, 737-743. [CrossRef]

13. Ahmad, W.; Ullah, N.; Xu, L.; El Sabagh, A. Global food and nutrition security under changing climates. Front. Agron. 2022, 3, 799878. [CrossRef]

14. Ahmad, W.; Ullah, N.; Zia, M.H. Soil contamination with metals: Sources, types and implications. In Soil Remediation and Plants: Prospects and Challenges; Academic Press: Cambridge, MA, USA, 2015; pp. 37-61.

15. Al-Wabel, M.I.; Rafique, M.I.; Ahmad, M.; Ahmad, M.; Hussain, A.; Usman, A.R.A. Pyrolytic and hydrothermal carbonization of date palm leaflets: Characteristics and ecotoxicological effects on seed germination of lettuce. Saudi J. Biol. Sci. 2019, 26, 665-672. [CrossRef] [PubMed]

16. Chan, K.Y.; Van Zwieten, V.; Meszaros, I.; Downie, A.; Joseph, S. Agronomic values of green waste biochar as a soil amendment. Soil Res. 2007, 45, 629-634. [CrossRef]

17. Major, J.; Rondon, M.; Molina, D.; Riha, S.J.; Lehmann, J. Maize yield and nutrition during 4 years after biochar application to a Colombian Savanna oxisol. Plant Soil 2010, 333, 117-128. [CrossRef]

18. Uzoma, K.C.; Inoue, M.; Andry, H.; Fujimaki, H.; Zahoor, A.; Nihihara, E. Effect of cow manure biochar on maize productivity under sandy soil condition. Soil Use Manag. 2011, 27, 205-212. [CrossRef]

19. Chan, K.Y.; Van Zwieten, L.; Meszaros, I.; Downie, A.; Joseph, S. Using poultry litter biochar as soil amendments. Aust. J. Soil Res. 2008, 46, 437-444. [CrossRef]

20. Yamato, M.; Okimori, Y.; Wibowo, I.F.; Anshori, S.; Ogawa, M. Effects of the application of charred bark of Acacia mangium on the yield of maize, cowpea and peanut, and soil chemical properties in South Sumatra, Indonesia. Soil Sci. Plant Nutr. 2006, 52, 489-495. [CrossRef]

21. Walkley, A. A critical examination of a raid method for determining organic carbon in soils: Effect of variations in digestion conditions and of organic soil constituents. Soil Sci. 1947, 63, 251-263. [CrossRef]

22. Olsen, S.R.; Cole, C.V.; Watanabe, S.N.; Dean, L.A. Estimation of available phosphorus in soils by extraction with sodium bicarbonate. In Circular; U.S. Department of Agriculture: Washington, DC, USA, 1954; Volume 939, pp. 1-19.

23. Berg, M.G.; Ernest, H.G. Methods of Soil Analysis Used in the Soil Testing Laboratory at Oregon State University; Agricultural Experiment Station, Oregon State University: Corvallis, OR, USA, 1978.

24. Rui, Y.K.; Guo, J.; Huang, K.L.; Jin, Y.H.; Lou, Y.B. Application of ICP-MS to the detection of heavy metals in transgenic corn. Guang Pu Xue Yu Guang Pu Fen Xi = Guang Pu 2007, 27, 796-798.

25. Dharmakeerthi, R.S.; Chandrasiri, J.A.S.; Edirimanne, V.U. Effect of rubber wood biochar on nutrition and growth of nursery plants of Hevea brasiliensis L. Growth in an ultisol. SpringerPlus 2012, 1, 84. [CrossRef] 
26. Tesfaye, F.; Liu, X.; Zheng, J.; Cheng, K.; Bian, R.; Zhang, X.; Li, L.; Drosos, M.; Joseph, S.; Pan, G. Could biochar amendment be a tool to improve soil availability and plant uptake of phosphorus? A meta-analysis of published experiments. Environ. Sci. Pollut. Res. 2021, 28, 34108-34120. [CrossRef] [PubMed]

27. Borno, M.L.; Eduah, J.O.; Müller-Stöver, D.S.; Liu, F. Effect of different biochars on phosphorus (P) dynamics in the rhizosphere of Zea mays L. (maize). Plant Soil 2018, 431, 257-272. [CrossRef]

28. Havlin, J.; Balster, N.; Chapman, S.; Ferris, D.; Thompson, T.; Smith, T. Trends in soil science education and employment. Soil Sci. Soc. Am. J. 2010, 74, 1429-1432. [CrossRef]

29. Kocsis, T.; Kotroczó, Z.; Kardos, L.; Biró, B. Optimization of increasing biochar doses with soil-plant-microbial functioning and nutrient uptake of maize. Environ. Technol. Innov. 2020, 20, 101191. [CrossRef]

30. Widowati, W.; Asnah, A. Biochar effect at potassium fertilizer and dosage leaching potassium for two-corn planting season. $J$. Agric. Sci. 2014, 36, 65-71. [CrossRef]

31. Shehu, H.E.; Kwari, J.D.; Sandabe, M.K. Effects of N, P and K fertilizers on yield content and uptake of N, P and K by sesame (Sesamum indicum L.). Int. J. Agric. Biol. 2010, 12, 845-850.

32. Lehmann, J.; Rillig, M.C.; Thies, J.; Masiello, C.A.; Hockaday, W.C.; Crowley, D. Biochar effects on soil biota. Soil Biol. Biochem. 2011, 43, 1812-1836. [CrossRef]

33. Lehmann, J.; Silva, P.J., Jr.; Steiner, C.; Nehls, T.; Zec, W.; Glaser, B. Nutrient availability and leaching in an archaeological Anthrosol and a Ferralsol of the Central Amazon basin: Fertilizer, manure and charcoal amendments. Plant Soil 2003, 249, 343-357. [CrossRef]

34. Dekok, L.J.; Grill, D.; Hawkesford, M.J.; Schnug, E.; Stulen, I. Cost Action 829. Fundamental Agronomical and Environmental Aspects of Sulphur Nutrition and Assimilation in Plants; Office for Official Publications of the European Communities: Luxemburg, $1999 ;$ p. 105.

35. Malvi, U. Interaction of micronutrients with major nutrients with special reference to Potassium. Karnataka J. Agric. Sci. 2011, 24, 106-109.

36. Esmaili1, E.; Kapourchal, S.A.; Malakouti, M.J.; Homaee, M. Interactive effect of salinity and two nitrogen fertilizers on growth and composition of sorghum. Plant Soil Environ. 2008, 12, 537-546. [CrossRef]

37. Morrissey, J.; Guerinot, M.L. Iron uptake and transport in plants: The good, the bad, and the ionome. Chem. Rev. 2009, 109, 4553-4567. [CrossRef] [PubMed]

38. Zhang, S.H.; Li, X.Y.; Li, X.P.; Yuan, F.M.; Yao, Z.H.; Sun, Y.L.; Zhang, F.D. Crop yield, N uptake and nitrates in a fluvo-aquic soil profile. Pedosphere 2004, 14, 131-136.

39. Germida, J.J.; Janzen, H.H. Factors affecting the oxidation of elemental sulfur in soils. Fertil. Res. 1993, 35, 101-114. [CrossRef]

40. Fellet, G.; Marmiroli, M.; Marchiol, L. Elements uptake by metal accumulator species grown on mine tailings amended with three types of biochar. Sci. Total Environ. 2014, 468, 598-608. [CrossRef]

41. Nishiyama, R.; Kato, M.; Nagata, S.; Yanagisawa, S.; Yoneyama, T. Identification of Zn-nicotianamine and Fe $\mathrm{Fe}^{-2}$ deoxymugineic acid in the phloem sap from rice plants (Oryza sativa L.). Plant Cell Physiol. 2012, 53, 381-390. [CrossRef]

42. Zuchi, S.; Cesco, S.; Astolfi, S. High S supply improves Fe accumulation in durum wheat plants grown under Fe limitation. Environ. Exp. Bot. 2012, 77, 25-32. [CrossRef]

43. Kochanek, J.; Rochelle, M.S.; Martinez, C.; Dakuidreketi, A.; Mudge, A.M. Biochar for intensification of plant-related industries to meet productivity, sustainability and economic goals: A review. Resour. Conserv. Recycl. 2022, 179, 106109. [CrossRef] 